\title{
Experimental Atherosclerosis in Rabbits
}

\author{
Waleska C. Dornas', Tânia T. de Oliveira², Luis E. Franklin Augusto², Tanus J. Nagem \\ Universidade Federal de Ouro Preto ${ }^{1}$; Departamento de Bioquímica e Biologia Celular ${ }^{2}$; Universidade Federal de Viçosa ${ }^{3}$, Belo Horizonte, MG \\ - Brazil
}

\section{Summary}

Many researches have been conducted in experimental models in order to study the development of atherosclerosis from hyperlipidemia-inducing diets. Since rabbits are very sensitive to cholesterol-rich diets and accumulate large amounts of cholesterol in their plasma, their use as experimental models to evaluate the development of atherosclerosis is highly relevant and brings information on factors that contribute to the progression and regression of this condition that can be applied to humans. As such, this review includes studies on the atherogenic function of cholesterol based on rabbits as the experimental model, since they have become the most largely used experimental model of atherosclerosis.

\section{Introduction}

The importance of plasma lipoprotein and lipid metabolism abnormalities characterized by hyperlipidemia and/ or hypercholesterolemia as the cause of coronary heart diseases and potential atherosclerosis is increasingly being supported by a considerable number of population-based and epidemiological studies today ${ }^{1}$. Hypercholesterolemiainducing diets in rabbits have been largely used as a model to study the development of human atherosclerosis.

The first investigation on experimentally induced atherosclerosis dates back to 1908. Ignatowski used rabbits fed milk, meat and eggs and observed increased intimal thickness of the aorta. Later, Lubarsch $(1910,1912)$ and Steimbiss (1913) were able to develop atherosclerosis in the aorta of rabbits fed diets including internal organs such as liver, adrenal gland and muscle. These studies, as well as others, showed a causal effect of animal proteins; however, other researchers believe that the element of the diet that caused atherosclerosis was cholesterol rather than animal tissue proteins ${ }^{2}$.

In order to evaluate the theory of atherogenesis from cholesterol, Clarkson and Newburgh (1926) fed rabbits a

\section{Key words}

Atherosclerosis; cholesterol; hypercholesterolemia; rabbits.

Mailing address: Tanus Jorge Nagem •

Rua Tulipa, 357 - Esplanada - 30280-200 - Belo Horizonte, MG - Brazil E-mail: tanus@ufop.br

Manuscript received November 27, 2008; revised manuscript received June 29, 2009; accepted August 24, 2009. normal diet, with increasing doses of cholesterol of 25, 113, 253 or 507 mg/day, administered in capsules. Moderate atherosclerosis was found in $71 \%$ of the rabbits fed $507 \mathrm{mg} /$ day of cholesterol for 47-87 days. Meeker \& Kesten (1940, 1941) dissolved 60 or $250 \mathrm{mg}$ of cholesterol in vegetable oil and added it to the diet of rabbits for three months. The animals developed typical atherosclerotic lesions similar to those seen in humans, thus corroborating the theory that cholesterol was the precursor for the development of atherosclerotic vascular disease ${ }^{3}$.

In order to induce hypercholesterolemia in animals, cholesterol-containing diets have been used, and these vary from commercial chow supplemented with substantially different levels of cholesterol, to changes in the amount of lipids, carbohydrates and the different fat sources and contents, whether with or without cholic $\mathrm{acid}^{4}$. In our laboratory, we have been inducing hypercholesterolemia in rabbits by adding $1 \%$ of cholesterol to commercial chow in several studies with the purpose of investigating substances that can be further made viable as medications for the control of lipid metabolism, and also of developing tests of potential therapies and diagnosis between different experimental procedures ${ }^{5-12}$.

The objective of the present review was to make a critical analysis of the hypercholesterolemic effect of cholesterolrich diets in studies using rabbits as the experimental model that can lead to a better understanding of the biology of atherosclerosis in cardiovascular diseases.

\section{Experimental atherosclerosis}

For a better understanding of the relationship between disorders of cholesterol metabolism and atherogenesis, diet manipulation and the use of animals with inherited metabolic errors such as Watanabe Heritable Hyperlipidemic (WHHL) and St. Thomas Hospital (STH) rabbits to induce familial hypercholesterolemia and hyperlipidemia combined with hypercholesterolemia, respectively, have been the focus of many experiments. Today, gene deletion technology has made possible studies producing a variety of transgenic animal models with lipoprotein disorders but, despite this revolutionary breakthrough, many of these genetically modified animals have been fed cholesterol to accelerate atherogenesis ${ }^{2}$.

\section{Exposure to plasma cholesterol and endothelial dysfunction}

The term "endothelial dysfunction", which has an important implication in the management of cardiovascular diseases, is used to describe situations in which the endothelium loses its vasoprotective property, and represents the initial phase 
of several processes of vascular lesion such as mechanical damage; hypercholesterolemia; atherosclerosis; and systemic hypertension ${ }^{13}$. In addition, vascular endothelial relaxation in response to acetylcholine is decreased, thus leading to vasoconstriction and reduced blood flow, as demonstrated by Sun et $\mathrm{al}^{14}$ in cholesterol-fed rabbits, since this decreased vasodilation may be caused by the presence of lipid plaques in the aorta.

Rabbits receiving a supplementation of $1 \%$ cholesterol in their diets for 8-10 weeks show impaired endothelial vasodilation in the carotid artery ${ }^{15}$ and abnormalities of the nitric oxide (NO) synthesis, as demonstrated in atherosclerotic vessels ${ }^{16}$. Considering hyperlipidemia and atherosclerosis, aortic segments of hypercholesterolemic rabbits show significant reduction of endothelial nitric oxide synthase (NOS) in relation to controls ${ }^{17}$. Vasquez-Vivar et a ${ }^{18}$ reported that $\mathrm{BH} 4$, a cofactor for the synthesis of $\mathrm{NO}$ in the aorta of rabbits fed a hypercholesterolemia-inducing diet, was markedly reduced in comparison to normocholesterolemic rabbits. Oxygen-free radicals such as the superoxide anion can modulate the activity of endogenous NO in hypercholesterolemic rabbits ${ }^{19,20}$. Interestingly, this demonstrates that NOS expression reported in vascular smooth muscle of hypercholesterolemic rabbits ${ }^{21,22}$ is not able to dominate the defects of the endogenous vascular function.

The increase in basal nitric oxide and in endotheliumderived vasodilators is more significant in endothelium-intact aortic rings of female rabbits than in those of males and depends on circulating estradiol concentrations ${ }^{23}$. Therefore, females are less susceptible to a diet inducing atherosclerotic lesions than males, but it depends on the state of the arterial endothelium, as observed by Holm et al ${ }^{24}$. Estradiol inhibits monocyte adhesion to endothelial cells with transendothelial migration, components of an inflammatory response that continually occurs throughout the atherogenic process after induced hypercholesterolemia in rabbits ${ }^{25}$.

The development of interventions aimed at inhibiting atherosclerosis from cholesterol, and vascular dysfunction have received much attention because of this important association. L-arginine (a NOS substrate) depletion in animal models of atherosclerosis and hypercholesterolemia induces platelet aggregation, cell proliferation, and vascular monocyte accumulation, whereas endothelial-dependent vasoreactivity is improved in hypercholesterolemic rabbits treated with
L-arginine, thus attenuating the mechanisms of vascular lesion $^{26}$ and inhibiting neointimal proliferation ${ }^{27}$, which can be assessed by means of several endothelial cell markers proposed (Table 1).

Von Willebrand factor was recently studied in rabbits fed a cholesterol-rich diet for 30 days. Hypercholesterolemia was observed to induce increased levels of this factor, which later decreased after withdrawal of the cholesterol-rich diet. This showed a positive correlation with fatty streak formation in both study phases, while there was a decrease in vascular endothelial growth factor levels after withdrawal of the cholesterol-rich diet. This could be a reparative mechanism in the early atherosclerosis, and could also reflect endothelial cell damage ${ }^{28}$.

While evaluating the effects of hypercholesterolemia on the risk of atherosclerosis using C-reactive protein (CRP), Sun et $\mathrm{a}^{29}$ showed that CRP is frequently deposited in atherosclerotic lesions in rabbit models. Additionally, high plasma CRP levels are associated with the severity of hypercholesterolemia ${ }^{30}$.

Increased NO synthesis may be a defense mechanism to compensate $\mathrm{NO}$ inactivation and protect against factors that represent body damage, with nitrite being a potent metabolite correlated with fatty streak formation; this has already been studied in the short and long term in cholesterol-fed rabbits ${ }^{31}$.

Parallel to these findings, endothelial function of vascular segments has been proven to be the earliest alteration in atherogenesis. The functional impairment of endothelial cells is demonstrated in the clinical consequences, such as the occurrence of events subsequent to the progression of plaque formation in the intima (Figure 1).

\section{Atherosclerotic plaque formation}

The cholesterol-fed rabbit model is remarkable because of the rapid development of aortic lesions and low maintenance cost, and the typical diet to induce atherosclerosis involves supplementation of $0.5 \%$ to $4 \%$ cholesterol per weight for approximately 8 to 16 weeks. Under these conditions, rabbits rapidly become hypercholesterolemic (plasma cholesterol > 1,000 mg/dl), and the resulting lesions primarily consist of macrophage-derived foam cells ${ }^{32}$. However, the relationship between atherosclerotic lesion formation and hypercholesterolemia-inducing diets in rabbits is dependent on the cumulative exposure rather than on the

\section{Table 1 - Some structural markers of endothelial dysfunction}

\footnotetext{
Nitric oxide acts on several processes implicated in the pathogenesis of atherosclerosis and thrombosis, such as platelet adhesion; free radical formation; polymorphonuclear cell activation; lipoprotein oxidation; vascular smooth muscle and intima cell mitogenesis and proliferation; and others.

VonWillebrandfactoris presentinthesubendothelial regionand hasahemostaticfunctionthatstimulates plateletadhesion. Whenavesselis ruptured, bloodclotting occurs in response to endothelial lesion and platelet adhesion to the damaged surface of the vessel, and this occurs by means of Von Willebrand factor binding.

Vascularendothelialgrowthfactorisafunctionaland vascularprotectivefactorthatactsasanendogenous regulatoroftheendothelialintegrityfollowing damage, and its receptors are regulated in inflammation and proliferative disorders such as atherosclerosis and restenoses.

C-reactiveproteinisamarkerofsystemicinflammationanditsincreaseinplasmalevelsarealsorelatedtothepresenceandseverity ofcoronaryarteryatherosclerosis andtoanincreasedrisk ofacutecardiovascularevents.Corroboratingthisidea, thetransitionfromstabletounstableanginaisassociated withincreasedinflammatory activity, as verified by the elevation of plasma levels of C-reactive protein, cytokines and leukocytes.

Nitrite is a stable nitric oxide metabolite that has been reported as a good marker of the endothelial production of nitric oxide, while NO bioactivity is decreased. It is known as a preliminary event in atherosclerosis.
} 


\section{Review Article}

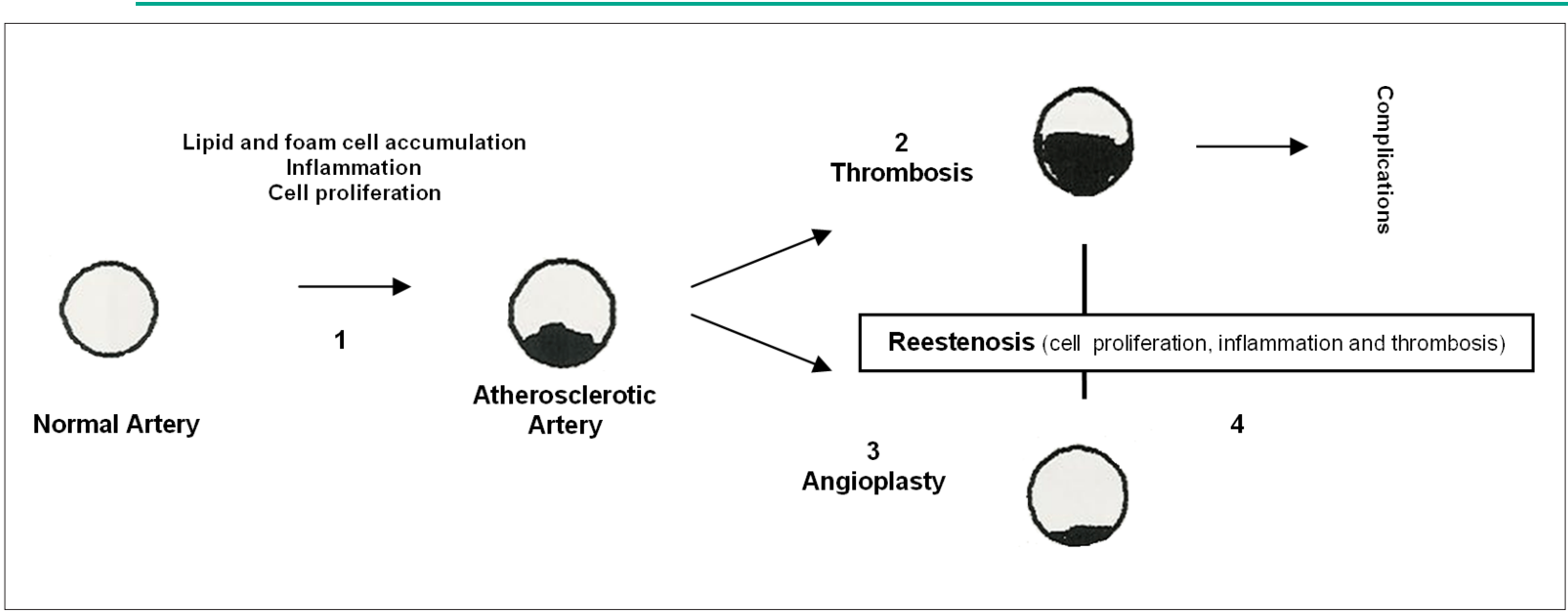

Figure 1 - Role of inflammation, smooth muscle cell proliferation and thrombosis in atherosclerosis lesion development. Endothelial injury and lipid (LDL) accumulation may initiate the atherogenic process (1). Activated macrophages and foam cells produce mitogens that induce migration of smooth muscle cells into intima and proliferation of these migrated cells in the intima may expose for thrombotic events (2). Occluded arteries can be opened by balloon angioplasty (3). These vessels, can be re-occluded through restenosis (4).

level of administered cholesterol, with rabbits fed $5.5 \%$ and $1.0 \%$ cholesterol showing similar degrees of induced hypercholesterolemia ${ }^{14}$. Some researchers support the suggestion that the formation of advanced lesions depends on the age of the animal. Aged rabbits, with 3-4.5 years of age, show fibrotic plaques, whereas young animals (4 months of age) do not show advanced lesions ${ }^{33}$.

Since rabbits have been widely used to study the development of atherosclerosis in humans, rapid development of lesions has been achieved by supplementing their diet with cholesterol $(<0.5 \%)$, thus reaching moderate hypercholesterolemia, with plasma cholesterol levels in the range of 200 to $800 \mathrm{mg} / \mathrm{dl}^{34}$. Consequently, the lesions usually produced are topographically and morphologically different from those seen in humans. This difference is partly due to the fact that humans do not usually eat large amounts of cholesterol: generally their plasma cholesterol levels do not exceed $800 \mathrm{mg} / \mathrm{dl}$, and they process and tolerate cholesterol intake better than rabbits. Additionally, long-term experiments in rabbits fed diets containing large amounts of cholesterol are discouraging due to hepatotoxicity and failure of the animal to thrive. Gross examinations revealed hepatomegaly with evidence of bile stasis at plasma cholesterol levels of 3,257 $\pm 266 \mathrm{mg} / \mathrm{dl}^{32}$. However, despite these restrictions, a large number of studies use this model to test the efficiency of drugs in the development of fatty streaks.

Atherosclerotic lesions are composed of three major components. The first is the cell component, which is predominantly comprised of smooth muscle cells and macrophages. The second component is the connective tissue matrix and extracellular lipid. The third is intracellular lipid, which accumulates within macrophages, then converting into foam cells ${ }^{35}$. In previous cell events, the presence of leukocytes adhered to the thoracic and abdominal aorta has been observed in rabbits fed a $0.2 \%$ cholesterol-enriched diet for three weeks. After 3-5 weeks on the same diet, numerous foam cells are found in the subendothelial space and constitute the development of fatty streaks in the same site where adherent monocytes had been previously observed ${ }^{36}$.

In the aorta, several types of plaques going from fatty streak to atheromatous lesions are observed in experimental models, depending on the degree of cholesterol intake. Diets containing $<0.15 \%$ cholesterol result in the development of fatty streak lesions, whereas atheromatous plaques are more frequently found when high amounts of cholesterol are present in the $\operatorname{diet}^{32}$.

The degree of atherosclerosis in rabbits tends to be greater in the abdominal aorta than in the thoracic aorta, and this can be explained by the hemodynamic effect or by the fact that the abdominal aorta of rabbits gradually tapers down to the aortic bifurcation. Therefore, the distal aorta may have more lesions than the proximal aorta ${ }^{37}$. Atheromatous changes after 8 weeks in rabbits fed cholesterol initiate in the thoracic aorta and then extend to the abdominal aorta, coronary artery and other vessels, with a predominance of concentric lesions in the thoracic aorta and proximal portion of the coronary artery in contrast to mild atherosclerosis found in the renal, carotid and femoral arteries in the 15th week of diet ${ }^{38}$. However, the extent to which the exposure to cholesterol influenced this type of lesion is not clear in this study.

The extent of atherosclerosis in the aorta of rabbits may be quantified by the area of sudanophilic lesions ${ }^{39}$ and by immunohistochemical analyses ${ }^{40}$. Recently, non-invasive magnetic resonance imaging (MRI) has been used in the study of vascular lesions. MRI quantification and changes in the composition of atherosclerotic plaques may be used with MRI to monitor the progression and regression of in vivo atherosclerosis. The advantage of this method is that serial studies may be conducted in order to verify the response to therapeutic interventions ${ }^{41}$.

Histological studies on the rate of stenosis, in turn, are an important method for the assessment of the severity of coronary atherosclerosis, because the rate is considered a direct reflex of the clinical condition. On the other 
hand, the assessment method using gross examination of atherosclerotic coronary arteries in rabbits has some advantages in relation to histological methods, since the analysis of the lesion area may be carried out in a short time, while the overall image of the atherosclerosis distribution may be easily understood. When tissue sections of atherosclerotic coronary lesions are necessary, it is possible to remove only the atherosclerotic plaque portion, which can be macroscopically observed from the luminal surface of the coronary artery ${ }^{42}$.

Vascular lesions play an important role in cardiovascular disorders, although the participation of hypercholesterolemia in thromboembolic events remains poorly understood, thus requiring a better understanding.

\section{Plaque rupture and thrombosis}

Rupture of the atherosclerotic plaque is known to be the major cause of thrombosis and subsequent clinical manifestations of atherosclerosis such as unstable angina, myocardial infarction and stroke, in addition to being a target of clinical intervention ${ }^{43-45}$. However, it is still difficult to predict when plaque rupture will occur, since the additional physiological stimulus required to trigger this event is unknown. The mechanisms of posterior plaque rupture and formation of subsequent occlusive thrombi remain not fully understood. Furthermore, it is still not clear whether plaques without thrombi can cause cardiac events ${ }^{44}$. Two main hypotheses have been proposed for the causes of plaque rupture (Table 2).

Several animal models of plaque rupture have been reported in the past few years. In cholesterol-fed rabbits, the lesion is commonly induced using an intravenously injected balloon containing Russel's viper venom and histamine, a procedure that will result in plaque rupture and thrombosis ${ }^{37}$. Another model is that of cholesterol-fed rabbits with implantation of a balloon catheter in the thoracic aorta. The balloon is inflated after the atherosclerotic lesion is formed around it, thus leading to lesion rupture and thrombosis ${ }^{46}$. However, both are models of acute mechanically-induced cases in a research context. Thus, the value of these models for the study of cell apoptosis, inflammation, increased lipids, and degradation of the fibrous capsule is limited due to different and marked characteristics of the plaques formed in these models in comparison to those found naturally in humans since, in the latter, the lesions are restricted to the subendothelial region, thus maintaining the integrity of the

\section{Table 2 - Causes of atherosclerotic plaque rupture}

The first hypothesis is that rupture results from a smooth muscle cell loss, and this can be the main producer of cap-stabilizing collagen caused by apoptosis, which can be mediated by the interaction between smooth muscle cells and monocytes/macrophages. The second hypothesis is that plaque rupture is the result of an imbalance between the production of plaque-stabilizing collagen on one hand and the action of corrosive enzymes on the other. These enzymes are present in the form of metalloproteinases, which derive mainly from macrophages and cathepsins, which cause the rupture of the collagenrich plaque cover. Additionally, inflammation also participates in plaque rupture by means of the production of procoagulation proteins. internal elastic layer ${ }^{47}$.

The atherosclerotic plaque is not a static structure. Rather, its status at any given moment is the result of the complex and dynamic interplay of a very large number of cellular and humoral factors ${ }^{48}$. Rekhter et $\mathrm{a}^{49}$ observed plaque destabilization determined by collagen breakdown with local loss of the cellular source of collagen synthesis in rabbits ${ }^{49}$. The authors demonstrated a time-dependent decrease in total collagen content in lipid-rich plaques, whereas the level of cross-linking did not differ between high and low cholesterol intake in the groups. A mechanical link between hypercholesterolemia and collagen loss is still hypothetical, although a critical function of macrophages and other proteolytic enzymes has been strongly suggested.

Hypercholesterolemia-inducing diet in rabbits selectively increases thrombus formation and embolism in arterioles, but not in venules. The observation that increased total plasma cholesterol results mainly in increased LDL cholesterol suggests that the effects seen of hypercholesterolemia on arteriolar thromboembolism are caused by LDL, and that the stimulus to endogenous $\mathrm{NO}$ production by excess $\mathrm{L}$-arginine is able to antagonize this increased cholesterol, hence this enhancement of arteriolar thromboembolism ${ }^{50}$.

If a thrombus is occlusive, it will lead to myocardial infarction ${ }^{45}$. Since plaque rupture is the main clinical complication, plaque stabilization is crucial, and a lipidlowering diet proved able to significantly reduce the proteolytic activity and increase the collagen content in atheromas established in rabbits ${ }^{51}$. The substantial degree of clinical benefit seems not to be proportional to the improvement in the stenosis produced by lipid lowering that stabilizes the atheromatous plaque by reducing the levels and activity of proteinases that can degrade key structural components of the arterial extracellular matrix ${ }^{51}$. Thus, the ability of the plaque to resist rupture is reinforced.

The administration of angiogenic growth factors is an interesting new approach to ischemic cardiac disease. Fibroblast growth factor promotes vascular repair and angiogenesis, inducing tissue factor expression in circulating monocytes and the vascular wall of normal and hypercholesterolemic rabbits ${ }^{52}$.

According to Abela et al ${ }^{53}$, rabbit models with arterial lesions that develop thrombosis after mechanical arterial wall injury and cholesterol-rich diet lead to plaques vulnerable to rupture and thrombosis, and can be used to test pharmacological agents that may reduce the development of vulnerable atherosclerotic plaques such as lipid-lowering agents; antioxidants; calcium channel blocking agents; and angiotensin-converting enzyme inhibitors. Antiplatelet and antithrombotic agents can be tested for their ability to reduce the amount of thrombus complicating plaque disruption. However, spontaneous plaque rupture does not occur in these models, although the triggering stimulus may lead to arterial thrombosis. Lesions produced in these animals by a combination of injury and a high-lipid diet lead to the formation of fibrous caps consisting of smooth muscle cells. Some aspects of human atheromas, typically formed in decades, may not be similar to those of atheromas obtained in a relatively short time in rabbit experiments ${ }^{51}$. 


\section{Review Article}

\section{Metabolic regulation in hypercholesterolemic rabbits}

Rabbits are an animal species that have several aspects similar to those of humans as regards the lipoprotein metabolism, except for hepatic lípase defficiency ${ }^{54}$. Several characteristics of rabbits make them an excellent model for the assessment of effects of human transgenes on lipoprotein metabolism and susceptibility to atherosclerosis: 1) apoB-containing lipoproteins are similar to those seen in humans ${ }^{55}$; 2) rabbit liver produces apoB-100-containing VLDL, like in humans ${ }^{56}$; 3) abundance of ester-transfer protein in rabbit plasma ${ }^{57}$.

At least four mechanisms are responsible for cholesterol homeostasis and affect plasma cholesterol concentrations (Table 3).

In rabbits, $7 \alpha$-hydroxylase activity and mRNA levels are inhibited after a hypercholesterolemia-inducing diet with significantly high plasma cholesterol levels ${ }^{58}$. However, Overturf et $\mathrm{al}^{59}$ found that by feeding rabbits a diet supplemented with $0.1 \%$ cholesterol for 7 months, this did not induce hypercholesterolemia, whereas by gradually increasing diet cholesterol intake, the bile acid pool increased inversely to $7 \alpha$-hydroxylase activity ${ }^{60}$.

Bile acid excretion increases the clearance rate, which decreases the effective concentration of intracellular cholesterol, thus inhibiting the influence of cholesterol on the expression of LDL receptors, since bile acids are predominantly reabsorbed via the enterohepatic circulation and return to the liver to exert a negative feedback control on the $7 \alpha$-hydroxylase enzyme and to regulate cholesterol metabolism ${ }^{61}$.

Bile acids are known to be reabsorbed in the intestine via passive and active mechanisms. Passive uptake occurs via non-ionic, ionic and micellar diffusion of conjugated or unconjugated bile acids; active, $\mathrm{Na}^{+}$-dependent, saturable absorption of conjugated bile acids occur against a concentration gradient. It has been proven that several species, rabbits included, have both bile acid reabsorption processes ${ }^{62}$. However, they have minimal passive intestinal reabsorption due to the relative hydrophilic nature of conjugated bile acids. The primary site of bile acid reabsorption is predominantly mediated by the ileal $\mathrm{Na}+$ /bile acid (IBAT) cotransporter and the interruption of the enterohepatic circulation of bile acids through attenuation of intestinal bile acid reabsorption is considered one of the best pathways for the reduction of plasma cholesterol levels ${ }^{62}$. Higaki et al ${ }^{63}$ used IBAT inhibitor

\section{Table 3 - Mechanisms responsible for cholesterol homeostasis}

a) Synthesis via acetate as a regulator by formation of mevalonic acid to
3-hydroxy-3-methylglutaryl coenzime $A$ which is catalyzed by the rate-limiting
enzyme HMG-CoA reductase;

b) LDL-receptor expression, especially in the liver, where more than half of the receptors are located, with a decrease in plasma cholesterol accompanied by decreased LDL levels;

\section{c) Diet cholesterol intake;}

d) Transformation of cholesterol into bile acid, the largest catabolic pathway for cholesterol which, regulated by formation of 7 a-hydroxycholesterol, is catalyzed by 7a-hydroxylase enzyme. and demonstrated a reduction in the amount of bile acid return to the liver and increased conversion of cholesterol into bile acid in cholesterol-fed rabbits.

The inhibitory effect of diet cholesterol on $7 \alpha$-hydroxylase in rabbits can help explain why some individuals are more sensitive to diet cholesterol and have their plasma cholesterol concentration increased. These individuals may respond to a high-cholesterol diet with a decreased bile acid synthesis, thus contributing to the elevation of plasma cholesterol levels and reduction of LDL receptors. Alternatively, other individuals respond to a cholesterol-rich diet with increased bile acid synthesis and, thus, plasma cholesterol levels do not increase. Identifying these individuals may help determine their atherosclerosis risk so that more sensible recommendations can be made for dietary treatment ${ }^{58}$.

\section{Final considerations}

Considering that the prevalence of atherosclerosis and ischemic heart disease is increasing worldwide, with serious clinical consequences that require efforts for a better understanding of their pathogenesis, it is clear that the search for improved experimental techniques and new therapies for these conditions is necessary, seeing the advances in the use of experimental models.

In this sense, rabbits as experimental models are an important tool for the study of atherosclerosis among the animals that have been used in clinical investigations. Among the animals studied, only rabbits show a tendency to develop hypercholesterolemia via accumulation of exogenous cholesterol after a few days receiving high-cholesterol diets, since their sterol excretion cannot be increased. However, careful extrapolations should be made in relation to the degree of hypercholesterolemia produced in laboratory animals, since they exceed the levels usually found in humans. Limitations and advances should be discussed so that they can contribute to and broaden the knowledge on the etiology, pathophysiology and treatment of atherosclerosis with the characterization of these findings.

\section{Acknowledgements}

The authors thank Fundação de Amparo à Pesquisa de Minas Gerais (FAPEMIG) for the financial support and research grant, and Rede Mineira de Toxicologia e Farmacologia - TOXIFAR, FAPEMIG.

\section{Potential Conflict of Interest}

No potential conflict of interest relevant to this article was reported.

\section{Sources of Funding}

This study was funded by FAPEMIG.

\section{Study Association}

This article is part of the thesis of master submitted by Waleska Cláudia Dornas, from Universidade Federal de Outo Preto. 


\section{References}

1. Sociedade Brasileira de Cardiologia. Sociedade Brasileira de Endocrinologia. II Consenso Brasileiro sobre dislipidemias. Detecção, avaliação e tratamento. Arq Bras Endocrinol Metab. 1999; 43: 287-305

2. Moghadasian MH. Experimental atherosclerosis: a historical overview. Life Sci. 2002; 70 (8): 855-65.

3. Kritchevsky D. Dietary protein, cholesterol and atherosclerosis: a review of the early history. J Nutr. 1995; 125 (3): 587S-593S.

4. Lichtman AH, Clinton SK, Iyama K, Connelly PW, Libby P, Cybulsky MI. Hyperlipidemia and atherosclerotic lesion development in LDL receptordeficient mice fed defined semipurified diets with and without cholate. Arterioscler Thromb Vasc Biol. 1999; 19 (8): 1938-44.

5. Percegoni N, Oliveira TT, Nagem TJ, Lima LRP, Lima EQ, Matta SLP. Efeito de caseína, proteína isolada de soja e colestiramina em coelhos hiperlipidêmicos. Rev Cienc Farm. 2004; 25: 99-110.

6. Oliveira TT, Nagem TJ, Pinto AS, Lopes RM, Camini NA, Leão MA, et al. Ação de chitosan e naringenina em coelhos hiperlipidêmicos. Rev Portuguesa de Farmácia. 2001; 1: 43-8.

7. Lima LRP, Oliveira TT, Nagem TJ, Pinto AS, Stringheta PC, Tinoco ALA, et al. Bixina, norbixina e quercetina e seus efeitos no metabolismo lipídico de coelhos. Braz J Vet Res Anim Sci. 2001; 38 (4): 196-200.

8. Lima LRP, Oliveira TT, Nagem TJ, Pinto AX, Tinoco ALA, Silva JF, et al. Ação terapêutica e inocuidade no metabolismo de quercetina, bixina e norbixina em coelhos hiperlipidêmicos. Tecnol Cien Agropec. 2008; 2 (1): 51-6.

9. Lima LRP, Oliveira TT, Nagem TJ, Pinto AS, Oliveira MGA, Tinoco ALA, et al. Rutina e bixina do urucum e suas ações hipolipidêmicas em coelhos. Rev Bras Farm. 2000; 81 (3): 58-62.

10. Lima LRP, Oliveira TT, Nagem TJ. Efeitos do flavonóide quercetina e dos corantes bixina e norbixina sobre parâmetros sanguíneos de coelhos. Rev Nutr. 2003; 16 (3): 305-14.

11. Lima LRP, Oliveira TT, Nagem TJ, Pinto AS, Oliveira MGA, Tinoco ALA, et al. Controle de hiperlipidemia em coelhos tratados com flavonóides e corantes naturais do urucum. Rev Acta Farmacêutica Boanarense (Buenos Aires). 2001; 20 (1): 53-7.

12. Virtuoso LS, Oliveira TT, Nagem TJ, Pinto AS, Tinoco ALA. Efeitos de rutina, colestiramina e betalaína no controle de lipídeos em soros de coelhos hiperlipidêmicos. Rev Bras Anal Clin. 2001; 33 (2): 85-9.

13. Iturry-Yamamoto G, Alves AA, Picon PD. Propriedades anti-aterogênicas do fator relaxante derivado do endotélio (óxido nítrico). Arq Bras Cardiol. 1997; 69 (5): 349-57.

14. Sun YP, Lu NC, Parmley WW, Hollenbeck CB. Effects of cholesterol diets on vascular function and atherogenesis in rabbits. Exp Biol Med. 2000; 224 (3): 166-71.

15. Laight DW, Matz J, Caesar B, Carrier MJ, Anggard EE. Investigation of endogenous nitric oxide vascular function in the carotid artery of cholesterolfed rabbits. Br J Pharmacol. 1996; 117 (7): 1471-4.

16. Kawashima S, Yokoyama M. Dysfunction of endothelial nitric oxide synthase and atherosclerosis. Arterioscler Thromb Vasc Biol. 2004; 24 (6): 998-1005.

17. Jiménez A, Arriero MM, López-Blava A, González-Fernandez F, Garcia R, Fortes J, et al. Regulation of endothelial nitric oxide synthase expression in the vascular wall and in mononuclear cells from hypercholesterolemic rabbits. Circulation. 2001; 104 (15): 1822-30.

18. Vasquez-Vivar J, Duquaine D, Whitsett J, Kalyanaraman B, Rajagopalan S Altered tetrahydrobiopterin metabolism in atherosclerosis: implications for use of oxidized tetrahydrobiopterin analogues and thiol antioxidants. Arterioscler Thromb Vasc Biol. 2002; 22 (10): 1655-61.

19. Harrison DG, Ohara Y. Physiologic consequences of increased vascular oxidant stresses in hypercholesterolemia and atherosclerosis: implications for impaired vasomotion. Am J Cardiol. 1995; 75 (6): 75B-81B.

20. Matz J, Andersson TLG, Ferns GAA, Änggard EE. Dietary vitamin E increases the resistance to lipoprotein oxidation and attenuates endothelial dysfunction in the cholesterol-fed rabbit. Atherosclerosis. 1994; 110 (2): 241-9.
21. Verbeuren TJ, Bonhomme E, Lbie M, Simonet S. Evidence for induction of a non-endothelial NO synthase in aortas of cholesterol-fed rabbits. J Cardiovasc Pharmacol. 1993; 21 (5): 841-5.

22. Pomerantz KB, Hajjar DP, Levi L, Gross SS. Cholesterol enrichment of arteria smooth muscle cells upregulates cytokine-induced nitric oxide synthesis. Biochem Biophys Res Commun. 1993; 191 (1): 103-9.

23. Hayashi T, Fukuto JM, Ignarro LJ, Chaudhuri G. Basal release of nitric oxide from aortic rings is greater in female rabbits than in male rabbits: implications for atherosclerosis. Proc Natl Acad Sci USA. 1992; 89 (23): 11259-63.

24. Holm P, Andersen HL, Arroe G, Stender S. Gender gap in aortic cholesterol accumulation in cholesterol-clamped rabbits: role of the endothelium and mononuclear-endothelial cell interaction. Circulation. 1998; 98 (24): 2731-7.

25. Nathan L, Pervin S, Singh R, Rosenfeld M, Chaudhuri G. Estradiol inhibit leukocyte adhesion and transendothelial migration in rabbits in vivo: possible mechanisms for gender differences in atherosclerosis. Circ Res. 1999; 85 (4) 377-85

26. Nematbakhsh M, Haghjooyjanmard S, Mahmoodi F, Monajemi AR. The prevention of endothelial dysfunction through endothelial cell apoptosis inhibition in a hypercholesterolemic rabbit model: the effect of L-arginine supplementation. Lipids Health Dis. 2008; 7: 27

27. Knopfholz J, Précoma DB, Brofman PRS, Bier GE, da Silva RFKC, Silva APK, et al. Efeito da L-arginina na neoproliferação intimal e no remodelamento arterial após lesão por balão, em ilíacas de coelhos hipercolesterolêmicos. Arq Bras Cardiol. 2006; 87: 520-4.

28. Haghjooyjavanmard S, Nematbakhsh M, Monajemi A, Soleimani M. Von Willebrand factor, C-reactive protein, nitric oxide, and vascular endothelia growth factor in a dietary reversal model of hypercholesterolemia in rabbit. Biomed Pap Med Fac Univ Palacky Olomouc Czech Repub. 2008; 152 (1): 91-5.

29. Sun H, Koike T, Ichikawa T, Hatakeyama K, Shiomi M, Zhang B, et al. C-reactive protein in atherosclerotic lesions: its origin and pathophysiological significance. Am J Pathol. 2005; 167 (4): 1139-48.

30. Hernández LR, Lundberg U, Arocha-Piñango CL. Experimental thrombosis I: relation with fibrinogen and other haemostatic parameters. Thromb Res. 2000; 99 (3): 295-305.

31. Minor RL, Myers PR, Guerra R Jr, Bater JN, Harrison DG. Diet-induced atherosclerosis increases the release of nitrogen oxides from rabbit aorta. J Clin Invest. 1990; 86 (6): 2109-16.

32. Kolodgie FD, Katocs AS Jr, Largis EE, Wrenn SM Cornhill JF, Herderick EE, et al. Hypercholesterolemia in the rabbit induced by feeding graded amounts of low-level cholesterol: methodological considerations regarding individual variability in response to dietary cholesterol and development of lesion type. Arterioscler Thromb Vasc Biol. 1996; 16 (12): 1454-64.

33. Spagnoli LG, Orlandi A, Mauriello A, Santeusanio G, de Angelis C, Lucreziotti $\mathrm{R}$, et al. Aging and atherosclerosis in the rabbit. 1. Distribution, prevalence and morphology of atherosclerotic lesions. Atherosclerosis. 1991; 89 (1): 11-24

34. Holvoet P, Collen D. Beta-VLDL hypercholesterolemia relative to LDL hypercholesterolemia is associated with higher levels of oxidized lipoproteins and a more rapid progression of coronary atherosclerosis in rabbits Arterioscler Thromb Vasc Biol. 1997; 17 (11): 2376-82.

35. Crowther MA. Pathogenesis of atherosclerosis. Hematology. 2005: 436-41.

36. Rosenfeld ME, Tsukada T, Gown AM, Ross R. Fatty streak initiation in Watanabe Heritable Hyperlipemic and comparably hypercholesterolemic fat-fed rabbits. Arteriosclerosis. 1987: 7 (1): 9-23.

37. Johnstone MT, Botnar RM, Perez AS, Stewart R, Quist WC, Hamilton JA, et al. In vivo magnetic resonance imaging of experimental thrombosis in a rabbit model. Arterioscler Thromb Vasc Biol. 2001; 21 (9): 1556-60.

38. Kamimura R, Suzuki S, Sakamoto H, Miura N, Misumi K, Miyahara K. Development of atherosclerotic lesions in cholesterol-loaded rabbits. Exp Anim. 1999; 48 (1): 1-7.

39. Staprans I, Pan X-M, Rapp JH, Feingold KR. Oxidized cholesterol in the diet accelerates the development of aortic atherosclerosis in cholesterol-fed 
Dornas et al

Experimental atherosclerosis in rabbits

\section{Review Article}

rabbits. Arterioscler Thromb Vasc Biol. 1998; 18 (6): 977-83.

40. Nakazato K, Ishibashi T, Shindo J, Shiomi M, Maruyama Y. Expression of very low density lipoprotein receptor mRNA in rabbit atherosclerotic lesions. Am J Pathol. 1996; 149 (6): 1831-8.

41. Helft G, Worthley SG, Fuster V, Fayad ZA, Zaman AG, Corti R, et al. Progression and regression of atherosclerotic lesions: monitoring with serial noninvasive magnetic resonance imaging. Circulation. 2002; 105 (8): 993-8.

42. Kitajima S, Sakuma S, Morimoto M. Macroscopic distribution of coronary atherosclerotic lesions in cholesterol-fed rabbits. Exp Anim. 1998; 47 (4) 221-7.

43. Lee RT, Libby P. The unstable atheroma. Arterioscler Thromb Vasc Biol. 1997; 17 (10): 1859-67.

44. Shiomi M, Ito T, Yamada S, Kawashima S, Fan J. Correlation of vulnerable coronary plaques to sudden cardiac events: lessons from a myocardial infarction-prone animal model (the WHHLMI rabbit). J Atheroscler Thromb. 2004; 11 (4): 184-9.

45. Libby P. Molecular bases of the acute coronary syndromes. Circulation. 1995; 91 (11): 2844-50.

46. Rekhter MD, Hicks GW, Brammer DW, Work CW, Kim JS, Gordon D, et al. Animal model that mimics atherosclerotic plaque rupture. Circ Res. 1998; 83 (7): 705-13.

47. Uint L, Laurindo FR, Lopes EA, Da-Luz PL. Ballon-induced endothelial denudation promotes deep injury of the arterial wall. Braz J Med Biol Res. 1989; 22 (7): 913-5

48. Cullen P, Baetta R, Bellosta S, Bernini F, Chinetti G, Cignarella A, et al. MAFAPS Consortium. Rupture of the atherosclerotic plaque: does a good animal model exist? Arterioscler Thromb Vasc Biol. 2003; 23 (4): 535-42.

49. Rekhter MD, Hicks GW, Brammer DW, Hallak H, Kindt E, Chen J, et al. Hypercholesterolemia causes mechanical weakening of rabbit atheroma. Circ Res. 2000; 86 (1): 101-8.

50. Broeders MA, Tangelder GJ, Slaaf DW, Reneman RS, Oude Egbrink MG. Hypercholesterolemia enhances thromboembolism in arterioles but not venules: complete reversal by L-arginine. Arterioscler Thromb Vasc Biol. 2002; 22 (4): 680-5

51. Aikawa M, Rabkin E, Okada Y, Voglic SJ, Clinton SK, Brinckerhoff CE, et al. Lipid lowering by diet reduces matrix metalloproteinase activity and increases collagen content of rabbit atheroma: a potential mechanism of lesion stabilization. Circulation. 1998; 97 (24): 2433-44.
52. Corseaux D, Meuride T, Six I, Rugeri L, Ezekowitz MD, Rouvier P, et al. Basic fibroblast growth factor increases tissue factor expression in circulating monocytes and in vascular wall. Circulation. 2000; 101 (16): 2000-6.

53. Abela GS, Picon PD, FriedI SE, Gebara OC, Miyamoto A, Federman M, et al. Triggering of plaque disruption and arterial thrombosis in an atherosclerotic rabbit model. Circulation. 1995; 91 (3): 776-84.

54. Moghadasian MH, Frohlich JJ, McManus BM. Advances in experimental dyslipidemia and atherosclerosis. Lab Invest. 2001; 81 (9): 1173-83.

55. Chapman MJ. Animal lipoproteins: chemistry, structure, and comparative aspects. J Lipid Res. 1980; 21: 789-853.

56. Greeve J, Altkemper I, Dieterich J-H, Greten H, Windler E. Apolipoprotein $B$ mRNA editing in 12 different mammalian species: hepatic expression is reflected in low concentrations of apoB-containing lipoproteins. J Lipid Res. 1993; 34 : 1367-83

57. Nagashima M, McLean JW, Lawn RL. Cloning and mRNA tissue distribution of rabbit cholesteryl ester transfer protein. J Lipid Res. 1988; 29: 1643-9.

58. Xu G, Salen G, Shefer S, Ness GC, Nguyen LB, Parker TS, et al. Unexpected inhibition of cholesterol 7 alpha-hydroxylase by cholesterol in New Zealand white and Watanabe heritable hyperlipidemic rabbits. J Clin Invest. 1995; 95 (4): 1497-504.

59. Overturf ML, Smith SA, Hewett-Emmett D, Loose-Mitchell DS, Soma MR, Gotto AM Jr, et al. Development and partial metabolic characterization of a dietary cholesterol-resistant colony of rabbits. J Lipid Res. 1989; 30 (2): 263-73.

60. Xu G, Shneider BL, Shefer S, Nguyen LB, Batta AK, Tint GS, et al. Ileal bile acid transport regulates bile acid pool, synthesis, and plasma cholesterol levels differently in cholesterol-fed rats and rabbits. J Lipid Res. 2000; 41 (2): 298-304.

61. Poorman JA, Buck RA, Smith SA, Overturf ML, Loose-Mitchell DS. Bile acid excretion and cholesterol $7 \alpha$-hydroxylase expression in hypercholesterolemia-resistant rabbits. J Lipid Res. 1993; 34 (10): 1675-85.

62. Aldini R, Ussia G, Roda A, Cilioni CG, Rizzoli R, Calcaterra D, et al. Evaluation of the ileal absorption capacity for bile acids in the rabbit. Eur Surg Res. 1990; 22 (2): 93-100.

63. Higaki J, Hara S, Takasu N, Tonda K, Miyata K, Shike T, et al. Inhibition of ileal $\mathrm{Na}+$ /bile acid cotransporter by S-8921 reduces serum cholesterol and prevents atherosclerosis in rabbits. Arterioscler Thromb Vasc Biol. 1998; 18 (8): 1304-11. 